\title{
Blinding of freeze-dried cod - a recipe developed for the FAST project
}

\author{
Heidi Julius Schnoor ${ }^{1 *}$, Marianne Witten ${ }^{1}$, Ronald van Ree ${ }^{2}$, Fernandez-Rivas Montserrat ${ }^{3}$, Lars K Poulsen ${ }^{1}$ \\ From Food Allergy and Anaphylaxis Meeting 2011 \\ Venice, Italy. 17-19 February 2011
}

\section{Background}

The FAST project (Food Allergy Specific ImmunoTherapy) aims at the development of safe and effective treatment of food allergies. Classical allergen-specific immunotherapy (SIT) for treatment of food allergy using subcutaneous injections with food extracts has proven to be effective but too dangerous due to anaphylactic side-effects. FAST aims at developing a safe alternative by replacing food extracts with hypo-allergenic recombinant major allergens, the active ingredients of SIT. Fish allergy is caused by a single major allergen, parvalbumin. In phase I and II of the study randomized double-blind placebo-controlled trials will be performed. A recipe for fishblinding does not exist and is needed to determine the clinical reactivity when including patients in the trial and to assess efficacy in the Phase II trial.

\section{Double-blind placebo-controlled challenges}

The aim was to develop a recipe that could blind the highest possible amount of freeze-dried cod in the lowest amount of edible low-allergenic vehicle. Several recipes were developed and tried in the attempt to hide the texture and taste of the freeze-dried cod. A burger primarily made of minced chicken meat, onion, rice and spices was able to blind cod successfully. Cumin seed is an important ingredient, that has the ability to mask the taste of cod that would otherwise remain in the mouth after intake.

\section{Recipe for freeze-dried cod-blinding}

Freeze-dried cod powder (in active challenge)

Minced chicken meat

Onion, chopped

Olive oil

Flattened rice (rice flakes)

${ }^{1}$ Copenhagen University Hospital, Allergy Clinic, Gentofte, Denmark

Full list of author information is available at the end of the article
Thyme

Cumin seeds

Salt

Pepper

Turmeric

All ingredients are thoroughly mixed in a food processor, to a homogeneous paste. Formed to a burger and cooked in a pre-heated oven at $180^{\circ} \mathrm{C}$.

7 doses are given from $50 \mathrm{ug}$ - $4 \mathrm{~g}$ protein, accumulated dose of $22 \mathrm{~g}$ of cod fish. Preliminary testing (triangle test) show that it is not possible to tell the active challenge from placebo.

\section{Author details}

'Copenhagen University Hospital, Allergy Clinic, Gentofte, Denmark. ${ }^{2}$ AMC, Amsterdam, Netherlands. ${ }^{3}$ Fundacion Hospital Alorcon, Madrid, Spain.

Published: 12 August 2011

doi:10.1186/2045-7022-1-S1-P84

Cite this article as: Schnoor et al: Blinding of freeze-dried cod - a recipe developed for the FAST project. Clinical and Translational Allergy 2011 1(Suppl 1):P84.

Submit your next manuscript to BioMed Central and take full advantage of:

- Convenient online submission

- Thorough peer review

- No space constraints or color figure charges

- Immediate publication on acceptance

- Inclusion in PubMed, CAS, Scopus and Google Scholar

- Research which is freely available for redistribution 